\title{
Community Efforts of Tutup Ngisor in Maintaining Art and Cultural Traditions
}

\author{
Yohana Ari Ratnaningtyas* \\ Department of Arts Management, Faculty of Fine Arts, The Indonesian Institute of the Arts Yogyakarta, Yogyakarta, \\ Indonesia
}

\begin{abstract}
The objective of the study is to find out the cause of traditional art in the sub-village of Tutup Ngisor which still survive until now. Qualitative descriptive research is used to reveal data comprehensively in the field. Techniques of data collection are conducted by holding observations of various artistic activities that exist, semi-structured interviews with figures and leader of the arts community as well as studying some literature and previous studies. The results show that interpreting the tradition and change in art is addressed with wisdom, has become a strong foundation for the people of Tutup Ngisor sub-village in maintaining its traditions, maintaining the local values and being wise in facing of outside influences. This research is expected to provide a solution to the possibility of reviving an extinct local tradition and keeping the tradition alive well. Therefore it is necessary to have a good and clear management system in order to anticipate the development of the era so that the art community can continue to grow and develop.
\end{abstract}

Keywords: art community, traditional art that can survive.

\section{INTRODUCTION}

Currently, there are many kinds of community growing in society. Most people consider that community is related to territory or neighborhood. A community is also established as a result of various bonds such as territory, activity, cultural heritage, language, belief, or certain interest. The definition of a community itself is still indistinguishable [1].

In fact, a community is established not only by geographical reason but also by cultural heritage, language, belief, or certain interest as well. Brain clarifies that the key point of a community is the similar activity done collectively [2]. There are two elements forming a community; the people and the activity. A group of people will not form a community if they do not have a similar activity. Thus, the art community means a community where a group of people have the same awareness of art and intend to preserve its art through certain art activities in particular ways [3].

Indonesia has a variety of local communities with various traditions. They commonly live with all of their traditions, values, orientations, and ways of thinking in order to be able to keep their activities. Some of the communities have been extinct due to changes in society, and some others are in danger such as Srandul, Gejog

\footnotetext{
${ }^{*}$ Correspondence address: Yohana Ari Ratnaningtyas Email: yohanaarir@gmail.com Address: The Indonesian Institute of the Arts Yogyakarta, JI Parangtritis km 6.5, Bantul 55188, Yogyakarta.
}

Lesung and Jathilan in Sleman, Pekbung, and Langen Mondro Wanara in Bantul [4].

These phenomena, traditional art communities that have been or are almost extinct, happened since there was no regeneration from the elders to the youngsters. Thus, the transfer process of the culture to the youngsters became weak and incomplete. Consequently, some information was lost from time to time. In addition, limited human resources, tools, and financial supports were also causing these phenomena [5]. However, the most important things, in this case, is the lack of learning and management system as the basic factors that need to be solved immediately [6].

One of the local communities that continue to last with all of its art and cultural traditions is the traditional art community of Tutup Ngisor Sub-Village, Sumber Village, Dukun Sub-District, Muntilan, Magelang. Tutup Ngisor is located in the slope of Mount Merapi, about $10 \mathrm{~km}$ from Muntilan, Magelang, Central Java. Tutup Ngisor is one of 12 regions in Sumber Village [7].

Tutup Ngisor Community is one of few communities that depend on their life in agricultural sector but are still engaged arts in their daily life. In their daily routine as farmers, they express their enthusiasm for art by establishing and nurturing an art community. This art community is named Padepokan Tjipta Boedaya. This sub-village is also as the traditional art forerunner, central of activities, preservation, and movement agent for the surrounding villages. For Tutup Ngisor villagers, art is an inseparable component of their daily life and can 
motivate the spirit of art in Sumber Village. Many forms of art grow to be the local cultural traditions that continue to be nurtured [8].

Based on that fact, the objective of the study is to find out the cause of traditional art in the Sub-village of Tutup Ngisor that still survive until now. This discussion is expected to provide solutions to bring back local traditions that have been extinct and maintain the existing traditions.

\section{RESEARCH METHOD}

A qualitative descriptive method is used to explore a social phenomenon or reality by describing a number of variables related to the problem being studied systematically. Through this research, it is hoped that the problem of endurance and the existence of traditional art in Tutup Ngisor as the object of this study can be revealed and elaborated more comprehensively for a depth analysis.

The focus of this study is the traditional art community of Tutup Ngisor Sub-Village and all elements therein. We include the performers of the art activities, the figures in the community, the forms of art, their view on art, and how they construct the meaning of changes.

\section{Data Collection}

The first stages in data collection were conducted through the observations by following various art activities, in the form of art performances, either in or outside their local area (Table 1). The rehearsals undertaken was also observed. It aimed to see directly how art in this area run and was maintained.

Table 1. Art Performances in Tutup Ngisor

\begin{tabular}{|c|c|}
\hline Performance & Description \\
\hline \multicolumn{2}{|l|}{ Traditional } \\
\hline Wayang Orang & the performers play as the puppets \\
\hline Wayang Topeng & $\begin{array}{l}\text { the performers play as the puppets } \\
\text { wearing mask }\end{array}$ \\
\hline Wayang Kulit & the puppets are made from leather \\
\hline Ketoprak & traditional comedy play \\
\hline $\begin{array}{l}\text { Topeng Ireng (Toto } \\
\text { Lempeng Irama } \\
\text { Kenceng) }\end{array}$ & $\begin{array}{l}\text { Traditional dance with colorful } \\
\text { costumes and black headress }\end{array}$ \\
\hline \multicolumn{2}{|l|}{ Modern } \\
\hline $\begin{array}{l}\text { Wayang Gaul } \\
\text { (wayang wathon) }\end{array}$ & Modern puppets play \\
\hline Wayang Bocah & Children play as the puppets \\
\hline $\begin{array}{l}\text { Dayak Grasak } \\
\text { (Buto dance) }\end{array}$ & $\begin{array}{l}\text { A combination of Topeng Ireng and } \\
\text { Giant Dance }\end{array}$ \\
\hline Campur & $\begin{array}{l}\text { Mix performance (A combination of } \\
\text { wayang orang and dance) }\end{array}$ \\
\hline Kuda Lumping & $\begin{array}{l}\text { the performers dance by using small } \\
\text { horse made from bamboo }\end{array}$ \\
\hline Jalantur & a dance performed by women \\
\hline
\end{tabular}

Second, the interview is done by using purposive sampling technique that is only select informants who are considered expert about the art of Tutup Ngisor which includes artists, figures in the community. The depth interviews guidelines covering open-ended questions to explore relevant information to the problem under study. The interviews were carried out with the leader of Padepokan Seni Tjipta Boedaya (art community), and the leader of Sanggar Bangun Budaya (art course), the members of the art community, and randomly chosen people while watching the performances. Interviews are conducted both formally and informally, by visiting some houses, attending performances, or visiting some other places where researcher involvement can be developed.

Third, documentation and literature study is used to obtain secondary data about the problem of art traditions residing in the research area sourced from various available books. The literature is especially on art and culture that are directly related to the cases of art in the art community of Tutup Ngisor Sub-Village.

\section{Study Specification and Problems}

Previous research found the art as an integral part of life. Art is a noble legacy preserved and taught to the next generation. It is also affirmed that art is not for life, but life is to art and through art, it can build love to all God creatures. A review of literature is important so that no overlap of problems and solutions with the same answers. The specific, clear, and explicit descriptions of the problem is strongly expected from these study [7]. This description are expected to become the main source as a valuable information material of Tutup Ngisor sub-village, Muntilan Magelang. So that this study has the originality that can be accounted for [9].

The other research said that the people of Tutup Ngisor and surrounding are the traditional rural agricultural artists, which was reinforced by the presence of Padhepokan Seni Tjipta Boedaja, founded by Father Yoso Sudarmao in 1937. This art community is unshakable from all forms of external change, and always maintains a receptive attitude and does not pursue something excessive. They are open to anyone who wants to learn art there [8].

The research about the political issues of art explained, how the Tutup Ngisor art community must wrestle and adopt a strong wisdom attitude when faced with outside powers, state or 
cultural people, who tried to intervene in the art traditions residing in their communities. This is called the art politics of Tutup Ngisor community that maintain and sustain their cultural identity in the field of art [10].

$A$ research about the communities around Mount Merapi described how diverse communities must face government policies. On one hand, the government with a strong reason for safety wants them to move to a safer settlement. On the other way, residents still insist on surviving with the reason that they have enough (local) knowledge to monitor and explain mystically the activities of Merapi. The study conducted covering several areas on the slopes of Merapi, including Tutup Ngisor Sub-village [11].

From several studies as described above, this study clearly has different specifications. This study further wants to see how the traditional art community that is located in Tutup Ngisor society can still survive; exist even growing and become its own icon for the traditional art community around it. The question that arises later, how art as one of the wisdom of living in society Tutup Ngisor can survive in the midst of a tremendous flow of change? What kind of strategies they developed? How is the process of cultural strategy established and maintained within the Tutup Ngisor community? Some of these issues are the focus of research that distinguishes from pre-existing studies.

\section{RESULT AND DISCUSSION}

This part is divided into two sections. The first section discusses the art community of Tutup Ngisor from its establishment until now. The second section talks about how this art community constructs the meaning of traditions and changes. It consists of three sub-sections. The first sub-section explains the survival of this art community to keep its traditional arts and to react toward foreign influences entering into this community. Then the next sub-section illustrates the resistance and the struggle of Tutup Ngisor that cannot be detached from the capability and skill of the head and the committee in managing the arts and the people involved therein. The last part discusses how this community with all the processes of transformation, adaptation, and acculturation keep its art activities to be able to survive and develop sustainably.

\section{History of Tutup Ngisor Art Community}

It is believed by the local people that Tutup Ngisor Sub-Village was established by Kyai Tutup
(An Islamic figure named Tutup). Kyai Tutup was assumed as the courtier (a person who devotes himself to Surakarta Palace) isolating himself due to the situation at that time, the turmoil inside the palace related to Dutch colonials. Kyai Tutup in his isolation opened land and stayed in a mountainous area which is now known as Tutup. The name came from its location, the slope of Mount Merapi. One of Kyai Tutup's grandsons, Romo Yoso Soedarmo, has sons to continue, preserve, and develop the culture of the ancestor until now.

The art community of "Tutup Ngisor" was established in 1937. The history of art in this place was initiated in the 1920s by Romo (Priest) Yoso Soedarmo (1885 - 1990) [12]. He was the pioneer and the founder of the art community in this place. He started it by encouraging people to learn traditional Javanese arts among the people. Romo Yoso Soedarmo was initially a courtier in Kadipaten Mangkunegaran, Surakarta, who had an opportunity to learn the palace's arts like Wayang Wong, Wayang Kulit, Wayang Topeng, and other palace's traditional dances. He developed and hereditarily passed down that artistic expertise. He fused agricultural and art activities which later generated a farmer artist community. Sitras Anjilin is the seventh son of Romo Yoso becoming the Head of the Padepokan. He continues the performance art of Wayang Orang related to ritual ceremonies. With his six siblings, they work together to preserve and develop arts in Padepokan Tjipta Boedaya until now.

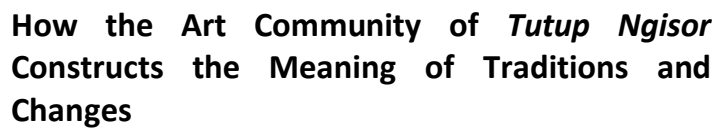
Changes

\section{Survival}

Survival is an ability to survive from various influences. There are two factors affecting survival ability, the internal factor and external factor [13]. The internal survival factor can be realized in the form of intention to continue doing and preserving art activities consciously and independently. On the other hand, the external survival factor is a condition where there are influences from outside of a community that cannot be prevented.

The geographical condition of Tutup Ngisor Sub-Village in the slope of Mount Merapi provides fertile land and abundant supply of water so that almost all of the people rely on the agricultural sector. The rice fields are cultivated 
based on peasantry customs and rituals as their ancestors once had.

The villagers of Tutup Ngisor live their daily life with mystical-spiritual cultural expressions reflected in the ceremony of Suran, Nyadran, Merti Dusun, Eid Al Fitr, and the Independence Day. In addition to preserving Javanese traditions, they also develop the Javanese traditional arts such as Wayang Kulit, Wayang Wong (Orang), Wayang Topeng, Kuda Lumping, and Klenengan 'caosan' Jumat Kliwonan.

Padepokan Tjipta Boedaya is indeed an art and cultural organization supported by a simple and firm community that is not affected by a range of changes infiltrating into every entity of life. The significant rituals in this community are the art performances and nurturing art and culture as parts of the agricultural customs and ceremonies. Such realities create a strong frame and foundation in every step taken by the art performers to survive in nurturing their traditional-ethnical arts.

Arts, especially dancing or playing traditional Javanese music, for the people of Tutup Ngisor are not so much different from planting chili or paddy. None is more important or more special since every activity is a ritual and blessing of life. It is just in line with Romo Yoso's teaching, never leave art in life. God is the most beautiful of all because God creates beauty. Art is inseparable from beauty created by humans to establish a physical and spiritual foundation of life expressed through various media. Thus, art is, in fact, a kind of social activities. Its presence reflects a collective expression that fits the characteristics of the related society, either as a form of aesthetic entertainment or as a spiritual communication medium with moral values intended to increase social solidarity.

The obligatory art performances of Padepokan Tjipta Boedaya are understood as a basic education of art passed from generation to generation. In a certain moment, people sing uyon-uyon of Gamelan Candi with Javanese gamelan accompaniment, complete with sinden and niyaga costume as a form of respect toward their ancestors. Kembang Mayang dance that is presented afterward expresses prayers for the fertility of their land and the fulfillment of the farmers' needs. That art performance is the ritual of Suran, a thanksgiving moment and a prayer to God as the Creator for His graciousness to the village.

By such performance, Padepokan Tjipta Boedaya has performed basic education of art in the slope of Mount Merapi and realized its dedication for the current generation [14]. That set of performance is held every 15 Suro (month in Javanese calendar). It is also a mandate from Romo Yoso as the respected elder and the Pepunden of people so that the village is always in the condition of Kertaraharjo, a condition of peaceful, prosperous, and contented agrarian society.

For Tutup Ngisor Community, art has a function as ingrained belief and religion that guide the life of the people. They believe that life is for art, not the otherwise. Because of that, there is a strong will to preserve Javanese arts and culture. The traditional arts developing a function to maintain the culture and art preservation of ethnic performances called kampung agraris (agrarian village) supported by farmer artists. The presence of Padepokan Tjipta Boedaya becomes the medium and the center of art activities in Tutup Ngisor, Sumber Village. By Romo Yoso's descendants, this place is used to practice Javanese arts and culture and to perform their artistic creation as a virtuous tribute to their ancestors.

To survive external factors, a community needs local wisdom and local genius. The definition of local wisdom is a local culture that determines the direction of a new culture as the result of cultural acculturation [15]. On the other side, local genius is the extraordinary ability of local society in processing external influences [16].

Hence, the policies taken by local public figures covers several aspects of life such as environment, the system of technology, buildings, beliefs, language, and art. They become the character or the identity of local culture in a physical or non-physical form, material (objective) or spiritual (subjective). Local wisdom and local genius that grow in the society of Tutup Ngisor are fostered and revealed through the orientation, perception, attitude, and way of life that based on the survival and the struggle of the society as the owner of the culture. In other words, local wisdom and local genius are fully supported by the capability of society in facing the challenge that concerns with human resource. The examples of new culture resulted from the acculturation are Wayang Wathon, Wayang Bocah, and Jalantur.

There are plenty of art enthusiasts from other places who come and train their artistic talent in this place. The name itself is already renowned in the artist community in Magelang. Experts of art 
and culture from Surakarta, Yogyakarta, Surabaya, Bandung, and Jakarta, even overseas come to learn, study, and document the art activities in this village. Now, the Padepokan is like a magnet that attracts enthusiasts, observers, researchers, and creators of performance arts and culture to come and see closer the heart of the art activities which then strengthens the identity this community.

\section{Art Community Management}

People who join a community are called community members. In some communities that have the structure of organization, they have the committee in addition to the members. Both the members and committee are people who join willingly and enjoy the activities in the community.

Having a lot of members is not enough for a community to be able to develop optimally [17]. The most important thing for a community is having the right people with the right skills, knowledge, and ability for the right job. The challenge in a community management is when the right man in the right place is suddenly inactive. To deal with that issue, the committee of the community should have proper skill and knowledge to manage its members. Most of the members of Tutup Ngisor Community are local youths who are active in every activity in the village. However, there are also adults (married men and women) and children participating in the community. Hence, it is not surprising that we can find the whole member of a family participating in the folk arts in Tutup Ngisor.

Basically, management is a way to make use any input to achieve maximum output through the process of planning, organizing, directing, and controlling by paying attention to the condition and situation of the environment. A management process needs to be carefully prepared to reach the goal of a community with a more effective and efficient manner. Thus, the management of performance art needs the management system of performance art [18].

The management of performance art is one good way to improve the quality and the quantity of performance art so that it can survive in the middle of the rapid progress of era and technology that leads to a modern society. Folk art management is a medium to realize the desire of local people in developing the existing folk art so that it can continue to exist in this modern world. A professional management will even provide the art performers a better life somewhere.

The management system applied in Tutup Ngisor community is very simple with only openness between them. By openness, the management process can be performed together with mutual trust and without suspecting each other. It means the management process of Tutup Ngisor is transparent, based on togetherness and mutual cooperation principles. In order to achieve the common goal, every member of the community needs to have a selfawareness to manage the community with their greatest effort. Tutup Ngisor Community in performing their activities implements their basic functions of management [19] that consist of:

\section{Planning}

As an organization with a modern point of view, Tutup Ngisor community designs the steps from every program and activity that they will perform. It is intended to create harmony and togetherness among them. Tutup Ngisor community is a team that upholds solidarity between its members to support the continuous development of the organization.

\section{Organizing}

The structure of the organization is very important so that every member knows their role and task in the art community of Tutup Ngisor. Organizing also eases the community in framing the workspace according to the member's expertise. Such workspace becomes an individual responsibility in every community's activity. A good organization is supposed to have the structure of an organization so that the tasks can be clearly divided in detail.

The art community of Tutup Ngisor has employed a systematic hierarchical structure along with its members. Its structure consists of advisor, head, deputy head, secretary, treasury, and public relation. On the other hand, every member has a different task. Each then holds an important role in the community. Some members of the committee are also the performers of the folk art so that those two responsibilities should be carried out in balance.

\section{Actualizing}

It covers the actions or activities performed by the art community of Tutup Ngisor, in both rehearsals and live 
performances. The head of this community motivates the committee by providing them with good examples in doing their jobs or solving a problem in the community. His wisdom and flexibility is a suitable method to engage the members of the committee to do their assignments as well. The leader also treats the members equally. He never treats them unfairly. In certain occasions, the manager will take the committee to participate in workshops for the sake of the community development. These workshops are usually intended to provide more knowledge about art and its management. Thus, by joining the seminars, the committee automatically will gain knowledge from outside of the community.

If a problem occurs, the head will carry out an individual approach toward the members, explore the issue carefully, and solve the problem personally. If the problem can be solved collectively, it will be solved as such.

The roles of the leader, in this case, are cultivating and maintaining a good relationship with the committee and the members of the community. The leader also gives motivation and guidance to assist the task completion, demonstrating good examples for the members, and emphasizing the sense of togetherness to maintain a harmonious relationship between the committee and the members of the community [20].

\section{Monitoring and Evaluating}

These functions are implemented when there is a failure in a program so that it can be addressed and corrected directly. Monitoring is the latest function of management. The advisor and the head monitor the activities of the committee and the members of the community so that they can be more focused. With the sense of togetherness applied by the art community of Tutup Ngisor, the monitoring function toward the committee is more on directing and assisting them in doing their job so that they do not feel under pressure. However, if there are any misappropriations, the head will correct them.

Monitoring the financial administration is performed together with the treasurer to control every income and expense. The financial monitoring is conducted openly and regularly to avoid any kind of mishandling. Income earned is used to upgrade the facilities and infrastructure of the community. When there is profit, it is shared equally no matter how small it is.

The monitoring process in this community is done in a wise and friendly way although sometimes it looks strict, all is for the smoothness of the activities. The head is also responsible for the loss resulted from the negligence of the committee. The evaluation process is carried out after the activity is finished. Every detail of the activity is broken down from the preparation, execution, and closing. Evaluating is an assessment to measure the effectiveness of the committee and the members of the community as well [21].

\section{Art Community Development}

The art performance in Tutup Ngisor SubVillage, Sumber Village has strong, valuable resistance and struggle character. It means, the inheritors and performers in giving the meaning the traditional art are always reminded to appreciate the value and attitude of their social environment. When the community meets with the foreign culture, dialectics occurs between them. The community responds by being resistant toward that foreign culture to protect their identity. The traditional performance arts like Wayang Wong (Orang), Wayang Gaul (Wayang Wathon), and Wayan Topeng are harmoniously coexistent with the field arts as Dayak Grasak, Campur, Kuda Lumping, and Jalantur.

As time goes by, the interaction between the art community of Tutup Ngisor and art community from other places, even international ones, occurs frequently. In facing rapid changes that come from the advancement of technology and communication, almost every person cannot delay the changes [22].

However, the people of Tutup Ngisor in Sumber Village deal with it by improving their capability in developing and maintaining social loyalty and solidarity in this agrarian village. This circumstance surprisingly strengthens the existence of traditional art as their cultural identity. Thus, it is obvious that the community is capable to reflect its local wisdom by showing their capability in transforming, selecting, innovating, adapting, acculturating, and tolerating foreign influences [23]. They construct the meaning of traditions and changes through 
the actualization of values of art to keep the messages. Thus the balance between generations is maintained and continued harmoniously.

The role of a community is enormous in the development of folk art so that it can be recognized outside their area. To keep its sustainable life and development, a positive development of community management is required [24]. The development of Tutup Ngisor community is a method to direct all of the community members to create new jobs for Tutup Ngisor people, increase income, upgrade the infrastructure, and improve the quality of the community in managing changes. Those changes can be in the forms of attitude, networking skill, and smart thinking in dealing with any kinds of problem from both inside and outside of the community [25].

In addition to the members involved in the art community of Tutup Ngisor, there are stakeholders that consist of families or neighborhood environment, government, business partners (for profit community), and volunteers. The role of these stakeholders is very significant. They can help the development of the community in providing more facilities, funding, licensing, and many more [26]. At a certain level, those stakeholders will take part in making decisions in the organization of the community.

So far, the art community of Tutup Ngisor has cooperated with many parties, including local and central government, non-governmental organizations, private companies, donors, print and electronic media, universities (state and private), and gallery communities or indigenous communities. However, the art community does not take sides or provide any political support for any of them since the principal of the cooperation is for the purpose of human empowerment and the development of art and culture.

\section{CONCLUSION}

The results show that interpreting the tradition and change in art is addressed with wisdom, has become a strong foundation for the people of Tutup Ngisor in maintaining its traditions, maintaining the local values and being wise in facing of outside influences. This research is expected to provide a solution to the possibility of reviving an extinct local tradition and keeping the tradition alive well. Therefore it is necessary to have a good management system and clear in order to anticipate the development of the era so that the art community can continue to grow and develop.

\section{REFERENCES}

[1] Bhattacharyya, J. 2004. Theorizing community development. Journal of the Community Development Society 34(2), 534.

[2] Borrup, T. 2011. The creative community builder's handbook: How to transform communities using local assets, art, and culture. Fieldstone Alliance. Saint Paul, MN.

[3] Baedhowi. 2010. Dinamisasi ruang antara praktik kosmologi dan sufisme dalam kesenian: sebuah model kearifan lokal komunitas budaya Lereng Merapi Magelang Jawa Tengah. $10^{\text {th }}$ Annual Confrence on Islamic Studies. Banjarmasin.

[4] Soedarsono, R. M. 2002. Seni pertunjukan Indonesia di era globalisasi. Gadjah Mada University Press. Yogyakarta.

[5] Cavaye, J. 2006. Understanding community development. Cavaye Community Development. Toowoomba, Australia. 1-34.

[6] Moss, M. L. and W. T. Grunkemeyer. 2010. Building shared visions for sustainable communities. Community Development 41(2), 240-254.

[7] Prabowo, S., Larasati, Suwarno, Isyanti, Maisa, Kurniawan and Hariyadi. 2012. Sanggar seni tradisi sebagai wahana pewarisan budaya lokal: Padepokan Tjipta Boedaja "Tutup Ngisor" Kecamatan Dukun Kabupaten Magelang. Balai Pelestarian Nilai Budaya DIY. Yogyakarta.

[8] Larasati, T. A. 2011. Komunitas kesenian Dusun "Tutup Ngisor" sebagai wahana pendidikan budaya untuk membentuk kepercayaan diri. Balai Pelestarian Sejarah dan Nilai Tradisional Yogyakarta. Jantra Jurnal Sejarah dan Budaya. Yogyakarta.

[9] Hersapandi. 2005. Suran: antara kuasa tradisi dan ekspresi seni. Galang Press and Pustaka Marwa. Yogyakarta.

[10] Salim, H. 2001. Festival: mengantar tradisi menjemput modernitas. Gong Magazine Special edition: Sorak-Sorai Festival.

[11] Laksono, P. M. 1985. Persepsi setempat dan nasional mengenai bencana alam: sebuah desa di Gunung Merapi. Peranan Kebudayaan Tradisional dalam Modernisasi. Yayasan Obor Indonesia. Jakarta. 189-214.

[12] Budiyanto, M. 2008. Pergulatan agama dan budaya: pola hubungan Islam dan budaya lokal di masyarakat "Tutup Ngisor", Lereng 
Merapi, Magelang Jawa Tengah. Jurnal Penelitian Agama 17(3), 649-668.

[13] Kester, G. H. 2004. Conversation pieces: community and communication in modern art. Univ of California Press. California.

[14] Maryanto, G. 2006. Berkunjung ke kaki gunung: sebuah percakapan dengan komunitas Tutup Ngisor. Teater Garasi. Yogyakarta.

[15] Geertz, C. 2008. Local knowledge: further essays in interpretive anthropology. Basic books. New York.

[16] Poespowardojo, S. 1986. Pengertian Local Genius dan relevansinya dalam modernisasi. In: Ayotrohaedi (Ed). Kepribadian Budaya Bangsa (Local Genius. Pustaka Jaya. Jakarta.

[17] McMillan, D. W. 1996. Sense of community. Journal of Community Psychology 24(4), 315-325.

[18] Stein, T. S. and J. Bathurst. 2008. Performing arts management: a handbook of professional practices. Skyhorse Publishing Inc. New York.

[19] Robbins, S. P. and M. A. Coulter. 2010. Management. Pearson Education.

[20] Darr, K. 2011. Chapter 7: introduction to management and leadership concepts, principles. In: Burke, R.E. and L. H. Friedman. Essentials of management and leadership in public health. Washington University. Washington DC.

[21] Butterfoss, F. D. 2006. Process evaluation for community participation. Annual Review of Public Health 27, 323-340.

[22] McCalman, J., R. A. Paton and S. Siebert. 2008. Change management: $A$ guide to effective implementation. SAGE.

[23] Barth, F. 1998. Ethnic groups and boundaries: the social organization of culture difference. Waveland Press. Illinois.

[24] Kay, A. 2000. Art and community development: the role the arts have in regenerating communities. Community Development Journal 35(4), 414-424.

[25] Long, H., S. Tu, D. Ge, T. Li, and Y. Liu. 2016. The allocation and management of critical resources in rural China under restructuring: problems and prospects. Journal of Rural Studies 47, 392-412.

[26] Lowe, S. S. 2000. Creating community: art for community development. Journal of Contemporary Ethnography 29(3), 357-386. 